University of Michigan Law School University of Michigan Law School Scholarship Repository

2009

\title{
The OECD Harmful Tax Competition Report: A Tenth Anniversary Retrospective
}

Reuven S. Avi-Yonah

University of Michigan Law School, aviyonah@umich.edu

Available at: https://repository.law.umich.edu/articles/38

Follow this and additional works at: https://repository.law.umich.edu/articles

Cart of the European Law Commons, Taxation-Transnational Commons, and the Tax Law Commons

\section{Recommended Citation}

Avi-Yonah, Reuven S. "The OECD Harmful Tax Competition Report: A Tenth Anniversary Retrospective." Brook. J. Int'l L. 34, no. 3 (2009): 783-95.

This Article is brought to you for free and open access by the Faculty Scholarship at University of Michigan Law School Scholarship Repository. It has been accepted for inclusion in Articles by an authorized administrator of University of Michigan Law School Scholarship Repository. For more information, please contact mlaw.repository@umich.edu. 


\title{
THE OECD HARMFUL TAX COMPETITION REPORT: A RETROSPECTIVE AFTER A DECADE
}

\author{
Reuven S. Avi-Yonah*
}

\section{INTRODUCTION: TWO VIEWS OF THE OECD REPORT}

F leven years ago the Organisation for Economic Co-operation and Development ("OECD") published its report "Harmful Tax Competition: An Emerging Global Issue"1 ("OECD Report" or "Report"). The Report identified for the first time two problem areas facing international income taxation of geographically mobile activities: tax havens and harmful preferential tax regimes. ${ }^{2}$ It sought to initiate activities to eliminate both types of problems. ${ }^{3}$

Over a decade has passed, and it is now time to consider the following: have the OECD Report and its progeny achieved anything useful? There have been two recent but contradictory answers to this question. On the one hand, J.C. Sharman concluded in his book on tax havens that the OECD effort was unsuccessful: "[b]y 2002 the small [S]tate tax havens had prevailed, and the campaign to regulate international tax competition had failed."4 On the other hand, Vaughn James argued as early as 2002 that the policy driven by the OECD Report has "robbed . . Caribbean countries of their sovereign right to determine their tax and economic policies."

These two views obviously cannot both be true. Either the tax havens have prevailed, or they have been crushed. Which view is correct? This Article will argue in Parts I and II that, overall, the OECD effort has been a success. The principal ground for this argument is data showing no decline in individual or corporate tax revenues in OECD member countries

* Irwin I. Cohn Professor of Law and Director, International Tax LL.M. Program, The University of Michigan Law School. I would like to thank Hugh Ault, Joe Guttentag, Phil West, and participants in the Tax Competition workshop at the Universite de Montréal for their helpful comments.

1. Comm. on Fisc. Aff., Org. for Econ. Co-Operation \& Dev., harmful Tax COMPETITION: AN EMERGING GLOBAL ISSUE (1998), available at http://www.oecd.org/ dataoecd/33/1/1904184.pdf [hereinafter OECD REPORT].

2. Id. $ๆ 4$.

3. See id. ๆ 90.

4. J.C. Sharman, havens in a Storm: The Struggle for Global Tax RegulaTION 1 (2006).

5. Vaughn E. James, Twenty-First Century Pirates of the Caribbean: How the Organization for Economic Cooperation and Development Robbed Fourteen CARICOM Countries of Their Tax and Economic Policy Sovereignty, 34 U. MIAMI INTER-AM. L. REV. 1, 2 (2002). 
over the past decade, in contrast with a decline in corporate tax revenues in non-OECD countries over the same period, as a result of tax competition among them and their failure to collect individual income taxes from the rich due to tax evasion.

However, more work remains to be done, and Part III of this Article argues that the OECD members could advance the objectives of the Report in two key ways: imposing a coordinated, refundable withholding tax on all payments to nontreaty jurisdictions; and strengthening tax rules for controlled foreign corporations ("CFCs") to combat preferential regimes in non-OECD countries.

\section{THE OECD REPORT AND ITS PROGENY ${ }^{6}$}

The original OECD Report focused on two issues. First, it identified "tax havens" as jurisdictions with (a) no or nominal income taxes and (b) at least one of three characteristics: lack of effective exchange of information, lack of transparency, and lack of substantial activities by taxpayers. ${ }^{7}$ Second, it identified "preferential regimes" as regimes offering (a) a no or low effective tax rate and (b) at least one of the following: ring fencing, lack of transparency, and lack of effective exchange of information. ${ }^{8}$ The OECD Report condemned both tax havens and preferential regimes as "harmful tax competition." 9

Following publication of the Report, the OECD began efforts to curtail preferential regimes in OECD member countries and to force tax havens to cooperate. In 2000, the OECD published a second report, focused in particular on how bank secrecy laws in many tax havens impeded their cooperation with international tax information requests. ${ }^{10}$ This report stated that all OECD countries should "permit tax authorities to have access to bank information, directly or indirectly, for all tax purposes so that tax authorities can fully discharge their revenue raising responsibilities and engage in effective exchange of information."

6. This section is based on a 2008 report by the U.S. Senate Permanent Subcommittee on Investigations. Staff of S. Comm. ON Homeland Sec. \& Gov. AfF., Perm. SubCOMM. ON INVESTIGATIONS, 110TH CONG., REPORT ON TAX HAVEN BANKS AND U.S. TAX COMPLIANCE 26-29 (2008), available at http://hsgac.senate.gov/public/_files/071708 PSIReport.pdf [hereinafter SENATE REPORT].

7. OECD REPORT, supra note 1, \23.

8. Id. $\ 27$.

9. See id. ๆ 4.

10. COMm. ON Fisc. AFF., ORG. FOR ECON. Co-Operation \& DeV., ImProving ACCESS TO BANK INFORMATION FOR TAX PURPOSES (2000), available at http://www.oecd. org/dataoecd/3/7/2497487.pdf [hereinafter OECD BANK INFORMATION REPORT].

11. Id. $ๆ 20$. 
As a result of these two reports, in mid-2000, the OECD published a list of thirty-five offshore jurisdictions that it planned to include in a subsequent list of "uncooperative tax havens" unless the countries agreed to remove "the harmful features of preferential regimes" by April 2003, and fully eliminated taxpayers' benefits under such regimes by December $2005 .^{12}$ Echoing the Report, in this document the OECD defined a "tax haven" as a country with (a) no or nominal taxation and (b) one or both of the following: ineffective tax information exchange with other countries, and a lack of transparency in its tax or regulatory regime, including excessive bank or beneficial ownership secrecy. ${ }^{13}$

Many countries did not want to appear on either the OECD's list of thirty-five offshore jurisdictions or its subsequent list of uncooperative tax havens. To avoid being included on the former, six jurisdictions, Bermuda, the Cayman Islands, Cyprus, Malta, Mauritius, and San Marino, gave the OECD signed commitment letters in April and May 2000, promising to provide effective tax information exchange by the specified deadlines. ${ }^{14}$ In response, the OECD omitted these countries from the list of thirty-five. ${ }^{15}$ To avoid appearing on the list of uncooperative tax havens, other countries provided similar commitment letters to the OECD later in 2000 and in 2001, and the OECD agreed to omit them from the updated list of uncooperative tax havens. ${ }^{16}$

Despite wavering support from the United States for the OECD effort, by 2002 , twenty-eight of the original thirty-five offshore jurisdictions identified by the OECD had committed to offering effective information

12. Comm. on Fisc. AfF., Org. for Econ. Co-Operation \& Dev., Towards Global TaX Co-operation: Progress in Identifying and Eliminating Harmful TaX PracTICES ๆף 4, 17-19 (2000), available at http://www.oecd.org/dataoecd/9/61/2090192.pdf [hereinafter 2000 PROGRESS REPORT].

13. Id. The OECD 2000 Progress Report did, however, omit from the definition the "lack of substantial activities by taxpayers," which would have limited the ability of taxpayers to set up pure shell corporations in tax havens. Compare id. $\$ 7$, with OECD REPORT, supra note 1, ๆ 23. For a critique of this change, see Michael C. Webb, Defining the Boundaries of Legitimate State Practice: Norms, Transnational Actors and the OECD's Project on Harmful Tax Competition, 11 REV. INT'L POL. ECON. 787-827 (2004).

14. See Comm. on Fisc. Aff., Org. for Econ. Co-Operation \& Dev., The OeCD'S Project on Harmful Tax Practices: The 2001 Progress Report 17 (2001), available at http://www.oecd.org/dataoecd/60/28/2664438.pdf [hereinafter 2001 PROGRESS REPORT].

15. See id:; 2000 PROGRESS REPORT, supra note 12, 17 (excluding these six jurisdictions from the list of thirty-five jurisdictions deemed "uncooperative tax havens").

16. See 2001 PROGRESS REPORT, supra note 14, I 22 ("Since the issuance of the 2000 Report, [five] jurisdictions have made commitments to eliminate harmful tax practices. They are Aruba, Bahrain, the Isle of Man, the Netherlands Antilles, and the Seychelles."). 
exchange in criminal and civil tax matters by the given dates. ${ }^{17}$ The result was that only seven jurisdictions were ultimately named on the OECD's official list of uncooperative tax havens, made public in mid-2002. ${ }^{18}$ Over time, four of the seven made the required commitments, so that, by 2008, the OECD's list had shrunk to just three countries: Andorra, Liechtenstein, and Monaco. ${ }^{19}$ To date, these three countries have persistently refused to provide tax exchange information with other jurisdictions in civil and criminal matters. ${ }^{20}$

While it was developing the lists of offshore jurisdictions and uncooperative tax havens, the OECD took a number of steps to advance global tax information exchange. In 2001, it established the Global Forum on Taxation, with participants drawn from OECD member countries and nonmember offshore jurisdictions, to discuss transparency and tax information exchange issues. ${ }^{21}$ In 2002, the OECD issued a model Agreement on Exchange of Information on Tax Matters that States could sign on a bilateral or multilateral basis to meet their commitments to tax information exchange. ${ }^{22}$ In 2004, to further promote the OECD's work, the G20 Finance Ministers issued a communiqué supporting the OECD's tax information exchange initiative and model agreement. ${ }^{23}$

17. See OECD, The OECD Issues the List of Unco-operative Tax Havens (Apr. 18, 2002), http://www.oecd.org/document/19/0,3343,en_2649_33745_2082323_1_1_1_1,00.html (listing Andorra, the Principality of Liechtenstein, Liberia, the Principality of Monaco, the Republic of the Marshall Islands, the Republic of Nauru, and the Republic of Vanuatu as the remaining "unco-operative tax havens").

18. See id.

19. OECD, List of Unco-operative Tax Havens, http://www.oecd.org/document/57/0, 3343,en_2649_33745_30578809_1_1_1_1,00.html (last visited Mar. 7, 2009).

20. Liechtenstein, however, is currently under pressure and has agreed to cooperate with the OECD. See EUbusiness.com, Liechtenstein Says Must Shed Tax Haven Image, Feb. 18, 2009, http://www.eubusiness.com/news-eu/1234957621.46/ ("Liechtenstein is ready to work with the OECD to overcome tax fraud, as the principality seeks to shed its image of an uncooperative tax haven ....").

21. See OECD, OECD Pursues a Global Dialogue on International Taxation (Oct. 1, 2001), http://www.oecd.org/document/23/0,3343,en_2649_33745_2367319_1_1_1_1,00.html.

22. See OECD, Agreement on Exchange of Information on Tax Matters, available at http://www.oecd.org/dataoecd/15/43/2082215.pdf (last visited Mar. 7, 2009). See also OECD, OECD Releases Model Agreement on Exchange of Information in Tax Matters (Apr. 18, 2002), http://www.oecd.org/document/4/0,3343,en_2649_33745_2082244_1_1_ 1_1,00.html.

23. G20, Meeting of Finance Ministers and Central Bank Governors: Communiqué, at 9 (Nov. 21, 2004), available at http://www.g20.org/Documents/2004_germany.pdf ("The G20 therefore strongly support the efforts of the OECD Global Forum on Taxation to promote high standards of transparency and exchange of information for tax purposes and to provide a cooperative forum in which all countries can work towards the establishment of a level playing field based on these standards."). 
In 2006, the OECD issued a new report assessing the legal and administrative frameworks for tax transparency and tax information exchange in eighty-two countries. ${ }^{24}$ The purpose of this assessment was to help the OECD determine "what is required to achieve a global level playing field in the areas of transparency and effect exchange of information for tax purposes." ${ }^{25}$ In October 2007, the OECD updated its eighty-two-country assessment. ${ }^{26}$ The OECD summarized its findings as follows:

Significant restrictions on access to bank information for tax purposes remain in three OECD countries (Austria, Luxembourg, Switzerland) and in a number of offshore financial centres (e.g. Cyprus, Liechtenstein, Panama and Singapore). Moreover, a number of offshore financial centres that committed to implement standards on transparency and the effective exchange of information standards developed by the OECD's Global Forum on Taxation have failed to do so. ${ }^{27}$

OECD-led efforts to promote tax information exchange are ongoing. In March 2007, the OECD sponsored a series of meetings among more than one hundred tax inspectors from thirty-six countries to discuss aggressive tax planning schemes within their jurisdictions. ${ }^{28}$ According to top OECD officials, the meetings indicated that key elements in most of these tax dodges could be traced to tax havens. ${ }^{29}$ In January 2008, the OECD held discussions among its members on taking "defensive measures" against tax havens that refuse to cooperate with tax information requests. ${ }^{30}$ Some OECD members have also recently called for expanding the list of uncooperative tax havens to include countries that, despite a written commitment, have failed to provide tax information upon request in criminal and civil matters. ${ }^{31}$

24. Global forum on taxation, OECD, Tax Co-operation: Towards a LeVel PLAYING FIELD (2006).

25. Id. at 7.

26. Global Forum on Taxation, OECD, Tax Co-operation: Towards a level PLAYING FIELD (2007).

27. OECD, OECD Reports Progress in Fighting Offshore Tax Evasion, but Says More Efforts Are Needed (Dec. 10, 2007), http://www.oecd.org/document/48/0,3343, en 2649_201185_39482288_1_1_1_1,00.html.

28. See, e.g., Richard Highfield, OECD Meeting with Mexican Legislators on Fiscal Policy and Finance: Tax Administration and the Reform Process, Mar. 27, 2007, http://gaceta. diputados.gob.mx/Gaceta/60/2007/jun/InfOCDE/Anexos.ppt/Archivol 1.ppt.

29. See Offshore Financial Centers Playing Key Role in Aggressive Tax Plans, OECD Official Says, BNA DAILY REPORT FOR EXECUTIVES, Mar. 27, 2007.

30. OECD Signals Plan to Renew Efforts Against Non-Cooperative Jurisdictions, BNA DAILY REPORT FOR EXECUTIVES, Oct. 15, 2007.

31. See Testimony of Jeffrey Owens, Senate Finance Committee Hearing on Offshore Tax Evasion (2007). 


\section{THE DATA}

The theoretical and practical basis for the concerns expressed in the OECD Report is laid out in detail elsewhere, ${ }^{32}$ so I will only summarize it here. In the last two decades, an increasing number of countries have competed for inbound investment by offering foreign corporate investors tax holidays. ${ }^{33}$ Multinational companies can with relative ease relocate production facilities in response to variations in foreign tax rates. Multinationals use such "production tax havens" to derive the bulk of their foreign income free of host country taxation. ${ }^{34}$ Furthermore, wishing not to damage the competitiveness of their multinational firms against multinationals based in other countries, the United States and most other developed countries balk at directly taxing foreign-source business income. ${ }^{35}$ If multinationals' foreign-source income were taxed by their home jurisdictions, new firms would migrate towards jurisdictions that leave such income effectively untaxed, ${ }^{36}$ creating a regime where corporate income earned abroad would largely be free of both host- and homecountry taxation.

For example, as a large multinational corporation, Intel Corporation has facilities in many countries that grant tax holidays: the company's major wafer fabrication facilities are in Ireland and Israel, and it also has assembly lines in China, Costa Rica, Malaysia, and the Philippines. ${ }^{37}$ Intel does not pay current U.S. tax on income from its foreign operations; according to U.S. law, income earned by U.S. multinationals' foreign

32. For an extensive discussion, see Reuven S. Avi-Yonah, Globalization, Tax Competition, and the Fiscal Crisis of the Welfare State, 113 HARV. L. REV. 1573 (2000) [hereinafter Fiscal Crisis]. See also Reuven S. Avi-Yonah, Bridging the North/South Divide: International Redistribution and Tax Competition, 26 MICH. J. INT'L L. 371 (2004) [hereinafter International Redistribution].

33. See Raymond Vernon, In the Hurricane's Eye: The Troubled Prospects of Multinational ENTERPRises 32 (1998); U.N. Conf. ON TRADE \& DEV., WORLD INVESTMENT RePORT 1996: INVESTMENT, TRADE aNd INTERNATIONAL POLICy ARRANGEMENTS 180 (1996).

34. See Rosanne Altshuler \& T. Scott Newlon, The Effects of U.S. Tax Policy on the Income Repatriation Patterns of U.S. Multinational Corporations, in STUDIES IN INTERNATIONAL TAXATION (Giovannini et al. eds., 1993); James R. Hines, Jr. \& Eric M. Rice, Fiscal Paradise: Foreign Tax Havens and American Business, 109 Q. J. ECON. 149 (1994).

35. See Robert J. Peroni, Back to the Future: A Path to Progressive Reform of U.S. International Income Tax Rules, 51 U. MIAMI L. REV. 975 (1997).

36. See James R. Hines, Jr., The Flight Paths of Migratory Corporations, $6 \mathrm{~J}$. ACCOUNTING, AUDITING \& FIN. 447, 451-52 (1991).

37. Intel Corp., Annual Report (Form 10-K), at 7 (Dec. 29, 2007), available at http://media.corporateir.net/media_files/irol/10/101302/2007annualReport/common/pdfs/ intel_2007ar.pdf. 
subsidiaries is taxed only after it is repatriated in the form of dividends, which Intel can defer indefinitely. ${ }^{38}$ Intel's effective tax rate on foreignsource income is therefore considerably lower than $35 \%$, the nominal rate at which U.S. corporations are taxed.

Should income derived from capital avoid the income tax net, the tax effectively becomes a tax on labor. In fact, as a number of empirical studies suggest, the effective tax rate on income from capital nears zero in some developed countries, and tax rates on capital have tended to noticeably decline since exchange controls were relaxed in the early $1980 \mathrm{~s}^{39}$ Jurisdictions that had previously relied on income tax revenues must resultantly supplement their tax revenue by raising more regressive taxes.

In OECD member countries, for example, consumption and payroll taxes, both more regressive than the income tax, have expanded the fastest: as a percentage of total revenues, consumption taxes rose from $12 \%$ in 1965 to $18 \%$ in 1995 , and payroll taxes increased from $19 \%$ to $27 \%$ during the same thirty-year span. ${ }^{40}$ Personal and corporate income taxes, however, failed to grow markedly as a percentage of total revenues between 1965 and $1995,{ }^{41}$ the personal income tax comprising $26 \%$ compared to $27 \%$ and the corporate income tax accounting for $9 \%$ versus $8 \%$, in these two years respectively. ${ }^{42}$ Additionally, between 1965 and 1994 , total tax revenue as a percentage of developed countries' gross domestic product ("GDP") increased sharply-from $28 \%$ to almost $40 \% .{ }^{43}$ This increase was mainly due to the increases in consumption and payroll tax rates. ${ }^{44}$ Evidence also suggests that as an OECD member economy becomes more open, taxes on labor tend to rise, but taxes on capital tend to fall. ${ }^{45}$

38. See Reuven S. Avi-Yonah, International Taxation of Electronic Commerce, 52 TAX L. REV. 507, 517 (1997) (discussing the "Single Tax Principle" under which foreignsource income is taxed in the residence jurisdiction at the tax rate for investment income).

39. See, e.g., DaNi Rodrik, Has Globalization GoNe TOO FAR? 63-65 (1997); Jeffrey Owens, Emerging Issues in Tax Reform: The Perspective of an International Bureaucrat, 15 TAX NOTES INT'L 2035, 2042-47 (1997).

40. Owens, supra note 39 , at $2038-40$.

41. Id.

42. Id.

43. INT'L Monetary Fund, Tax Policy HaNdBook 289-94 (Parthasarathi Shome ed., 1995).

44. Id.

45. See Enrique G. Mendoza et al., Effective Tax Rates in Macroeconomics: Estimates of Tax Rates on Factor Income and Consumption, 34 J. MONETARY ECON. 297, 321 (1994); Enrique G. Mendoza et al., On the Ineffectiveness of Tax Policy in Altering LongRun Growth (Ctr. for Econ. Pol'y Research Discussion Paper No. 1378, 1996). Insofar as the income tax is placed on capital and labor, its stability may conceal this trend. 
Similar trends may also be noted in countries that are not OECD members or located in the Middle East. These States' total revenues as a share of their GDP increased from an average of $18.8 \%$ between 1975 and 1980 , to $20.1 \%$ between 1986 and $1992 .{ }^{46}$ This growth, however, was principally financed through an increase in another revenue source-the value-added tax ("VAT"), which grew from $25.5 \%$ to $31.8 \%$ of total revenues over the $1980 \mathrm{~s} .{ }^{47}$ During this same period, individual and corporate income tax revenues remained flat, or even declined. ${ }^{48}$

A study by Keen and Simone illustrates both the extent of this problem and its impact on developing countries. ${ }^{49}$ Keen and Simone show that, from 1990 to 2001, corporate tax rates declined in both developed and developing countries. ${ }^{50}$ However, while in developed countries this decline in the rates was matched by a broadening of the tax base, so that no decline in revenues can be observed, ${ }^{51}$ in developing countries, the same period witnessed a decline of corporate tax revenues by about $20 \%$ on average. ${ }^{52}$ This decline is particularly important in light of the larger share of tax revenues produced by the corporate tax in developing countries (an average of 17\%) as opposed to developed countries (an average of $7 \%) .{ }^{53}$ Keen and Simone attribute most of this decline to the spread of targeted tax incentives for multi-national enterprises ("MNEs"). From 1990 to 2001, the percent of developing countries granting tax holidays to MNEs grew from $45 \%$ to $58 \%$, and similar trends can be seen for tax breaks for exporters ( $32 \%$ to $45 \%$ ), reduced corporate rates for MNEs $(40 \%$ to $60 \%)$, and free trade zones $(17.5 \%$ to $45 \%){ }^{54}$ These figures are particularly important because a companion paper by Altshuler and Grubert shows that the evolution of effective tax rates between 1992 and 1998 seem to have been driven by tax competition, and that U.S. manufacturers are becoming increasingly sensitive to tax considerations in determining the location of their investments. ${ }^{55}$

46. TAX POLICY HANDBOOK, supra note 43, at 295-303, 307-12.

47. See id. at 5 .

48. Id. at 295-303, 307-12.

49. Michael Keen \& Alejandro Simone, Is Tax Competition Harming Developing Countries More Than Developed?, 34 TAX NOTES INT'L 1317 (2004).

50. See id. at 1320.

51. See Rachel Griffith \& Alexander Klemm, What Has Been the Tax Competition Experience of the Last 20 Years?, 34 TAX NOTES INT'L 1299, 1301 (2004).

52. See Keen \& Simone, supra note 49 , at 1318.

53. Id. at 1318-21.

54. Id.

55. Rosanne Altshuler \& Harry Grubert, Taxpayer Responses to Competitive Tax Policies and Tax Policy Responses to Competitive Taxpayers: Recent Evidence, 34 TAX NOTES INT'L 1349 (2004). 
However, as Griffith and Klemm point out, there is no evidence that tax competition had a negative effect on OECD member countries, even if it led them to reduce tax rates. ${ }^{56}$ In fact, in those countries, both individual and corporate tax revenues have been remarkably stable on average from 1975 to 2006 . Total tax revenue as a percentage of GDP in OECD countries was $29.4 \%$ in 1975 , and $35.9 \%$ in $2006 .{ }^{57}$ Of this, individual taxes on income were $11.2 \%$ of GDP in 1975 , and $13 \%$ in $2006{ }^{58}$ Corporate taxes were $2.2 \%$ of GDP in 1975 , and $3.9 \%$ in $2006 .{ }^{59}$ Thus, while consumption taxes account for most of the increase in tax revenue in the era of globalization, there is no indication that either individual or corporate tax revenues have gone down in OECD countries as a result of tax competition.

It can be argued that these overall statistics are misleading, and that they represent a shift from income taxes paid by the rich on mobile capital to income taxes paid by salary earners who are less mobile. However, this argument does not explain the stability of the corporate tax, since most corporations do have the option of earning their income overseas. Moreover, the fact that in non-OECD countries the effects of tax competition are apparent in the data and lead to a decline in corporate tax revenue suggests that there is something occurring in the OECD countries that prevents such a decline from taking place. ${ }^{60}$ Similarly, it is striking that $O E C D$ countries succeed in taxing the rich through the income tax far more than developing countries. ${ }^{61}$

In my opinion, the OECD effort to curtail harmful tax competition has something to do with this achievement. As far as the corporate tax is concerned, the effort to cut back on preferential regimes in OECD mem-

56. Griffith \& Klemm, supra note 51, at 1299.

57. ORg. FOR ECON. Co-Operation \& Dev., Revenue Statistics 1965-2007, at 19 (2008).

58. Id. at 20 .

59. Id. at 21 . In the EU, the trends are similar: total tax revenue was $39.6 \%$ of GDP in 1995 and $39.9 \%$ in 2006; the implicit tax rate on capital (the most important part of which is the corporate tax) was $25.8 \%$ in 1995 , and $33.3 \%$ in 2006 , despite a decline in the corporate tax rate from $35.3 \%$ in 1995 , to $23.6 \%$ in 2006 . See TAXATION TRENDS IN THE EUROPEAN UNION (European Comm'n 2008), available at http://epp.eurostat.ec.europa.eu/ cache/ITY_OFFPUB/KS-30-08-421/EN/KS-30-08-421-EN.PDF.

60. This also addresses the critique that the reason corporate tax revenues are stable is the high profitability of corporations. Presumably, multinationals are just as profitable in developing countries, so without limits on preferential regimes, there would be a decline in profits in OECD countries as well.

61. See Richard M. Bird \& Eric M. Zolt, Redistribution via Taxation: The Limited Role of the Personal Income Tax in Developing Countries, 52 UCLA L. REV. 1627 (2005). 
ber countries, plus an increased vigilance on transfer pricing and a concerted effort to lower the permanent establishment ("PE") threshold, have all prevented a decline in corporate tax revenues that would otherwise have taken place. ${ }^{62}$

The U.S. corporate tax shelter saga is a good indication that these kinds of efforts can have a real impact on the numbers. From 1993 to 2003, there was a surge in corporate tax shelters in the United States, the consequence of which was a real decline in corporate tax revenues from $3 \%$ to $2 \%$ of GDP. ${ }^{63}$ In 2003 (following the Enron scandal and a Senate Hearing), the Internal Revenue Service ("IRS") began a serious crackdown on tax shelters, involving in particular an assault on the intermediaries (i.e., accounting firms and law firms) that were essential to devising and marketing the shelters. The result was a remarkable recovery in revenues to $4 \%$ of GDP, a level not seen since just after the 1986 Tax Reform Act (which significantly broadened the corporate tax base) ${ }^{64}$ This shows that crackdowns like the OECD harmful tax competition initiative can have a material effect on the macro revenue data.

With respect to individual income taxation, the recent stories from Liechtenstein and Switzerland demonstrate that, despite the OECD Report, there is still a lot of revenue lost to tax havens. ${ }^{65}$ The Senate Permanent Subcommittee on Investigation estimated the total amount of lost revenue for the United States alone at $\$ 100$ billion a year; other estimates are lower (i.e., $\$ 50$ billion) but still quite high.$^{66}$ However, the question is not how many people cheat, but how many more would have cheated but for the pressure on tax havens and the negative publicity generated by the OECD effort. In my opinion, if the OECD did not put pressure on tax havens, many more citizens of OECD countries would have transferred their funds to tax havens than the admittedly large numbers that currently do so. To the extent that OECD countries succeed in taxing the rich more

62. See Reuven S. Avi-Yonah, Tax Competition and E-Commerce, 23 TAX NotES INT'L 1395 (2001). On lowering the PE threshold, see, for example, Jean Pierre Le Gall, Can a Subsidiary Be a Permanent Establishment of Its Foreign Parent?, 60 TAX L. REv. 179 (2007); Lee Sheppard, Revenge of the Source Countries, 2006 TNT 200-3 (Oct. 17, 2006).

63. See Reuven S. Avi-Yonah, Senator McCain's Corporate Tax Proposals: A CRITICAL EXAMINATION $8 \mathrm{n} .7$ (2008), available at http://www.americanprogressaction. org/issues/2008/pdf/avi-yonah_paper.pdf.

64. See id.

65. See SENATE REPORT, supra note 6, at 32-114.

66. See id. at 1; Joseph Guttentag \& Reuven Avi-Yonah, Closing the International Tax Gap, in BridgING THE TAX GAP: AdDRESSING THE CRISIS IN FEDERAL TAX ADMINISTRATION 99, 101 (Max B. Sawicky ed., 2005). 
than developing countries, and all the evidence shows that they do, this is in large part because of efforts like the OECD Report.

\section{THE FUTURE}

Nevertheless, it is clear, and the OECD would not dispute, that the OECD's current efforts are not enough. What more can be done? In the corporate arena the answer is clear. While tax competition among OECD countries is on the wane, in large part because of OECD efforts, tax competition continues unabated among non-OECD countries, and in my view that is to their own detriment. ${ }^{67}$ The obvious solution is to strengthen the CFC rules. Since $90 \%$ or more of MNEs are headquartered in OECD countries, if all OECD jurisdictions abolished deferral, there would be no incentive for developing countries to engage in tax competition. New MNEs might be established in developing countries, but that is not necessarily a bad thing. The major impediment to adopting and strengthening CFC rules has been the fear of harming "your" MNEs in the face of competition from other MNEs. ${ }^{68}$ But if all OECD countries acted together, source-based taxation by developing countries could be saved with no harm to competitiveness. ${ }^{69}$

For taxation of individuals' income, the problem is similarly a matter of coordination. ${ }^{70}$ A principal problem of dealing with tax havens is that if even a few countries do not cooperate with information exchange, tax evaders are likely to shift their funds there from cooperating jurisdictions, thereby rewarding the noncooperating ones and deterring others from cooperation. Thus, some jurisdictions have advertised their refusal to cooperate with OECD efforts. Recent accounts about Liechtenstein illustrate this point.

However, if the political will existed, the tax haven problem could easily be resolved by rich States through their own actions. The key observation here is that funds cannot remain in tax havens and be productive; they must be reinvested into the prosperous and stable economies of the world (which is why some laundered funds that need to remain in the tax havens earn a negative interest rate). If the rich countries could agree, they could eliminate the tax havens' harmful activities overnight by, for example, imposing a refundable withholding tax (e.g., at $35 \%$ ) on pay-

67. See International Redistribution, supra note 32, at 9-12.

68. This fear has led numerous countries, including the United States, to relax their CFC rules. See Reuven S. Avi-Yonah, Back to the Future? The Potential Revival of Territoriality, 62 BULL. FOR INT'L TAX'N 471 (2008).

69. See Reuven S. Avi-Yonah, Tax Competition and Multinational Competitiveness: The New Balance of Subpart F, 18 TAX NOTES INT'L 1575 (1999).

70. See Guttentag \& Avi-Yonah, supra note 66. 
ments to noncooperating tax havens, or more broadly, to all nontreaty countries, and insisting on effective exchange of information with treaty countries. The withholding tax would be refunded upon a showing that the income was reported to the residence country.

The financial services industry would no doubt lobby hard against such a step, on the grounds that it would induce investors to shift funds to other OECD member countries. However, the EU and Japan have both committed themselves to taxing their residents on foreign-source interest income. The EU Savings Directive, in particular, requires all EU members to cooperate in exchange of information or impose a withholding tax on interest paid to EU residents. ${ }^{71}$ Both the EU and Japan would like to extend this treatment to income from the United States. Thus, this would seem an appropriate moment to cooperate with other OECD member countries by imposing a withholding tax on payments to tax havens that cannot be induced to cooperate in exchanging information, without triggering a flow of capital out of the OECD..$^{72}$

\section{CONCLUSION}

In the last decades of the twentieth century, there were frequent predictions that the income tax would be dead in the era of globalization. The distinguished Canadian economist Richard Bird wrote in 1988 that "the weakness of international taxation calls into question the viability of the income tax itself. . . . If something is not done to rectify these problems soon, the future of the income tax is bleak." 73 Other authors wrote papers with titles such as, "Can Capital Income Taxes Survive in Open Economies?"74 and "Is There a Future for Capital Income Taxation?"75 and I wrote one entitled "Globalization, Tax Competition, and the Fiscal Crisis of the Welfare State." 76

These obituaries for the income tax have proven premature. Within the OECD, income taxation is alive and well. In my opinion, part of this suc-

71. See generally Council Directive 2003/48, 2003 O.J. (L 157) (EC).

72. For a discussion of this proposal in a U.S. context, see Reuven S. Avi-Yonah, $A$ Coordinated Withholding Tax On Deductible Payments, Shelf Project Proposal, TAX Notes (June 2, 2008). Note that, for the United States, the authority to impose such a tax on interest payments already exists, so no change in the law is needed. Id.

73. Richard Bird, Shaping a New International Tax Order, 42 BULL. FOR INT'L FisCAL DOCUMENTATION 292, 303 (1988).

74. Roger H. Gordon, Can Capital Income Taxes Survive in Open Economies?, $47 \mathrm{~J}$. FIN. 1159(1992).

75. Jack Mintz, Is There a Future for Capital Income Taxation?, 42 CANADIAN TAX. J. 1469 (1994).

76. Fiscal Crisis, supra note 32. 
cess story is due to the OECD Report and its progeny. However, there are serious problems in non-OECD countries, and anecdotal evidence like the recent Senate Report confirms the continued existence of problems in OECD countries as well. If left unchecked, the dire predictions of a twenty-first century world based on the VAT, while perhaps premature, could in time still be borne out.

The OECD Report and its progeny represented a useful beginning. To complete the work, two steps are needed, both of which can be taken by the OECD countries if the political will exists: eliminate the ability of non-OECD countries to offer preferential tax regimes by eliminating deferral for all CFCs, and eliminate tax evasion by OECD residents by imposing a refundable withholding tax on payments to nontreaty countries while requiring real exchange of information by treaty countries. If these steps are implemented, the income tax can survive well into the next century. 